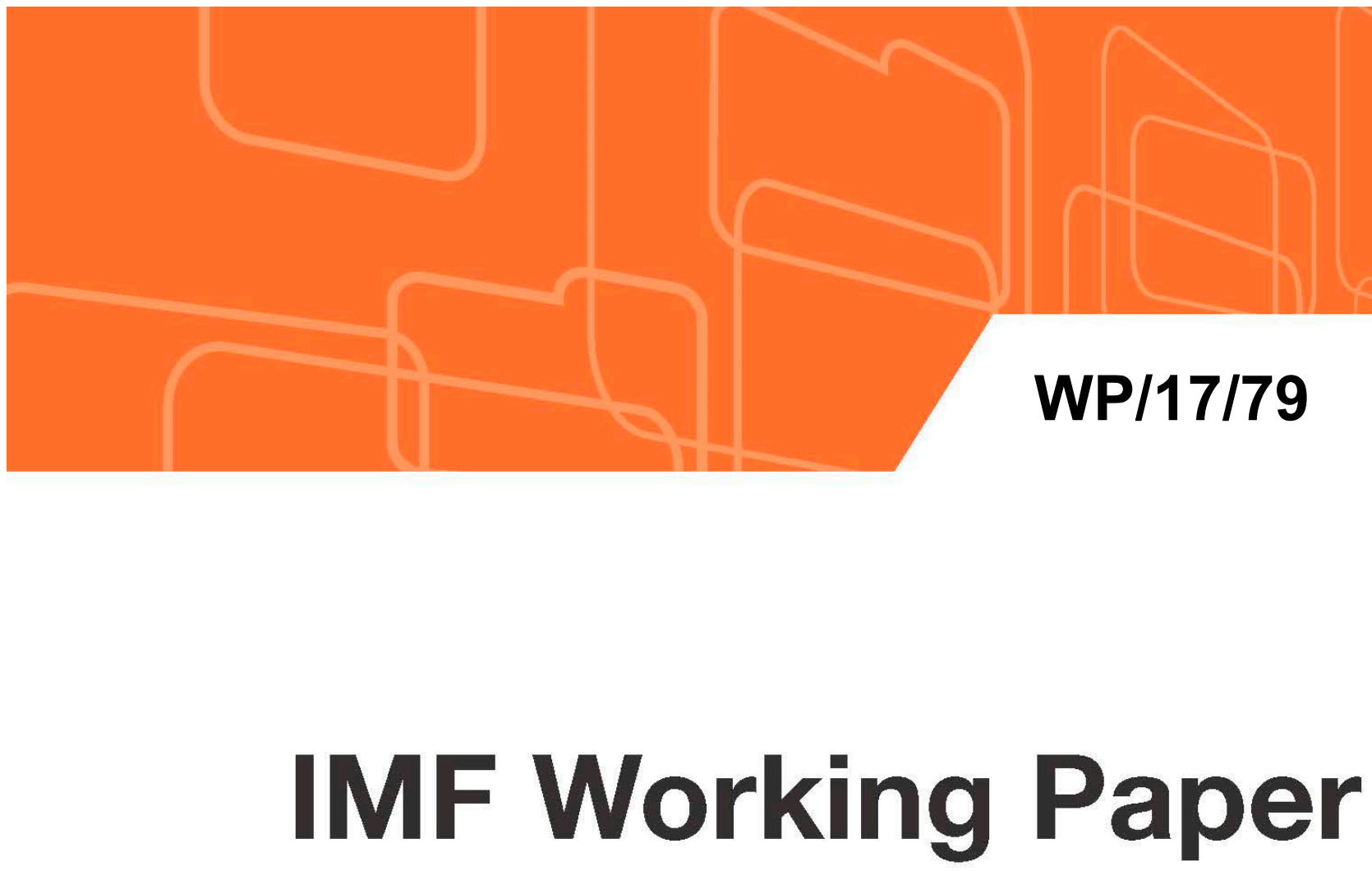

\title{
Education Systems and Foreign Direct Investment: Does External Efficiency Matter?
}

Elise Wendlassida Miningou and Sampawende Jules Tapsoba

IMF Working Papers describe research in progress by the author(s) and are published to elicit comments and to encourage debate. The views expressed in IMF Working Papers are those of the author(s) and do not necessarily represent the views of the IMF, its Executive Board, or IMF management. 


\title{
IMF Working Paper
}

Office of Executive Directors

\section{Education Systems and Foreign Direct Investment: Does External Efficiency Matter? Prepared by Elise Wendlassida Miningou and Sampawende Jules Tapsoba ${ }^{1}$}

Authorized for distribution by Daouda Sembene

March 2017

\section{IMF Working Papers describe research in progress by the author(s) and are published to elicit comments and to encourage debate. The views expressed in IMF Working Papers are those of the author(s) and do not necessarily represent the views of the IMF, its Executive Board, or IMF management.}

\begin{abstract}
This paper examines the effect of the efficiency of the education system on Foreign Direct Investment (FDI). First, it focuses on the external efficiency and applies a frontier-based measure as a proxy of the ability of countries to optimally convert the average years of schooling into income for individuals. Second, it shows the relationship between the external efficiency of the education system and FDI inflows by applying GMM regression technique. The results show that the efficiency level varies across regions and countries and appears to be driven by higher education and secondary vocational education. Similarly to other studies in the literature, there is no significant relationship between the average years of schooling and FDI inflows. However, this study shows that the external efficiency of the education system is important for FDI inflows. Improving the external efficiency of the education system can play a role in attracting FDI especially in non-resource rich countries, nonlandloked countries and countries in the low and medium human development groups.

JEL Classification Numbers: O15, I25, F23.
\end{abstract}

Keywords: FDI, Human Capital, Education System, External Efficiency.

Author's E-Mail Address: eminingou@globalpartnership.org; stapsoba@imf.org.

\footnotetext{
${ }^{1}$ The authors are grateful to Katharina Trapp for sharing her cross-country data on labor income shares.
} 
Table of Contents

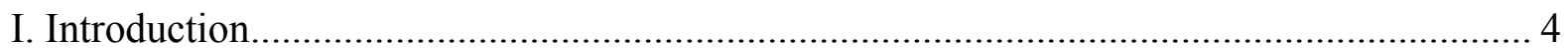

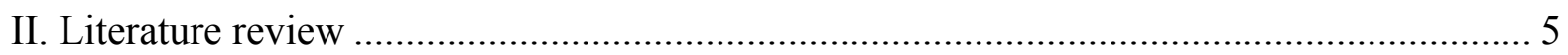

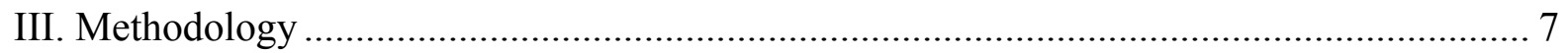

A. External efficiency of education and FDI: a formalization ......................................... 7

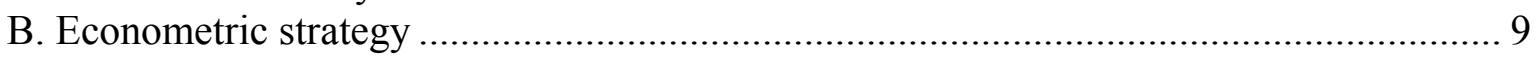

C. External efficiency of the education system........................................................... 9

IV. Data

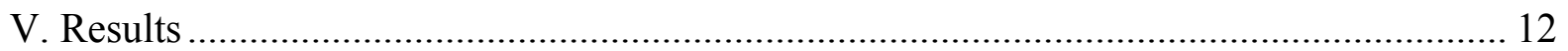

A. Estimate of external efficiency ………………………….................................... 12

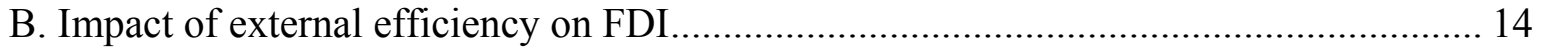

C. Extensions: sample heterogeneity......................................................................... 16

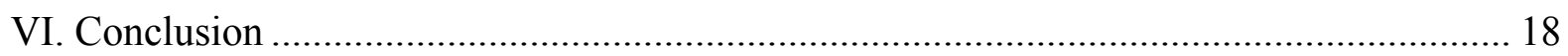

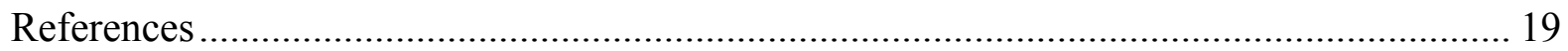

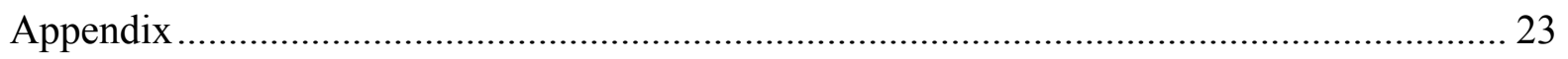




\section{INTRODUCTION}

Identifying Foreign Direct Investment (FDI)-friendly policies is crucial for policymakers. FDI is an important source of revenue for several countries. FDI helps fill the investment gap and is an excellent vehicle for technology transfer (Liu, 2008 and Keller, 2010). For these reasons, FDI-led growth is at the core of several growth strategies in many countries. At the same time, the quality of human capital is an essential ingredient for attracting FDI. Some studies examined the role of several barriers to FDI inflows and the quality of human capital appears to be one of the most challenging ones (e.g. Noorbakhsh, Paloni, and Youssef, 2001; Brooks, Hasan, Lee, Son, and Zhuang, 2010; Assuncao, Forte, and Teixeira, 2011). The current study focuses on the quality of the education related to the ability of countries to match the educated individuals' skills to the needs of the economy.

This study examines the adequacy of the education system in attracting FDI. The adequacy of the education system has been considered one of the drivers of the quality of human capital (Becker 1993 and Hanushek and Dennis 2000). Psacharopoulos (1986) was one of the pioneers that analyzed the issue of the adequacy of the education system through a model that measures the misallocation cost on the labor market emanating from the education system. Since Psacharopoulos (1986), the literature has explored different aspects of the adequacy of the education system to the labor market. Vincens (2005) focused on defining qualitative and quantitative adequacy of the education system while Plassard and Tran (2009) described over-education as another aspect of the education system inadequacy. Overeducation happens when the number of years of schooling is higher than the required education necessary to hold a given position. This is associated with a waste of resources. Topel (1997) made a clear difference between the static adequacy of the education system and the dynamic one. The static adequacy is more about matching the supply of skilled labor to the labor market demand at a given moment in the time; dynamic adequacy deals more with the future demand on the labor market and the adjustment in the education system accordingly.

The education systems around the World faces two types of efficiency issues: internal and external efficiency (World Bank, 2015). First, the internal efficiency is defined as the ability of the education system to use the education sector inputs to provide education services of high quality. Second, the external efficiency captures the notion of producing skilled labor that matches the demand on the labor market. The current study focuses on the external efficiency of the education system. The external efficiency of the education system is a typical example of the adequacy of the education system to the labor market. It refers to the ability of the education system to reflect the number of years of schooling in the income structure in the labor market. An efficient education system should lead to a perfect correlation between schooling years and wages. The concept of external efficiency of the education system builds on the theory of human capital which postulates that other things being equal, education tends to augment skills and productivity and raises workers' lifetime earnings (Sala-i-Martin, 2011). The external efficiency of the education system is the ability to reduce the misallocation between supply and demand for skilled labor. There is a consensus that in most countries, there are significant mismatches between the output of the education system (skilled labor supply) and the nature of demand for skilled workers in the 
labor market (Sala-i-Martin, 2011).

The external efficiency of the education system and FDI inflows are related for several reasons (Mouhoud, 2013). First, foreign investors may be attracted by the quality and the relevance of the expertise developed by the labor force in a given developing country. Second, it is well known that multinational firms are usually interested in subcontracting with countries' companies, especially in countries where the local labor force is highly qualified. Third, in the current context of globalization, offshoring appears to be a common alternative for international companies to boost their competitiveness, and countries where adequate trained labor force is available may attract investors.

This research assumes that the quality of the labor force training with regard to the needs of the economic activities, as captured by the level of external efficiency, matters in attracting FDI. To the best of our knowledge, this study is the first to make a causal link between the external efficiency of the education system and FDI. Using data from 1990 to 2010 on about 90 countries, a stochastic frontier model is applied to build a frontier of labor remuneration. The frontier is a proxy of the maximum labor remuneration that countries could achieve, given different levels of the average years of schooling. Countries with the most efficient education system lie on the frontier and are expected to get the maximum labor income given the average years of schooling achieved by the population. Deviations from the frontier capture the inefficiency with which the human capital level is translated into income in the domestic economies. The study proposes that there is a relationship between FDI inflows and the external efficiency of the education system.

The average efficiency is 44 percent, meaning that the same level of labor income could have been achieved with an average years of schooling that is 66 percent lower than its actual value if all countries were perfectly efficient. The efficiency level highly varies across countries and regions. After controlling for potential sources of endogeneity, results suggest a positive relationship between FDI and the external efficiency of the education system. Estimations suggest an increase of 18 percent in the FDI net inflow per unit of employment after a standard deviation improvement in the efficiency score. The rest of the paper is organized as follows: Section 2 presents a brief literature review on the relationship between human capital and FDI. Section 3 describes the theoretical and the econometric models. Results are provided in Section 4. Section 5 states the conclusion of the study.

\section{LiteratURE REVIEW}

The relationship between FDI and economic development is well documented in the literature. FDI could help countries, by not only increasing the stock of capital, but also improving the productivity of the economy through technology transfer. The literature shows that a cross-country technological diffusion exists that improves productivity and FDI is one of the major channels (Helpman, 1997; Miyamoto and Yasuyuki, 2006; Suyanto and Bloch, 2009 and Sheng and $\mathrm{Xu}, 2012$ ). Many countries rely on FDI to escape from the poverty trap. However, Borensztein, De Gregorio, and Lee (1998) and Xu (2000) found that FDI has a 
positive effect on productivity growth, as well as income growth only if the recipient country has reached a certain human capital level. Consequently, FDI is an important factor of economic growth and the level of human capital could strengthen the relationship between FDI and growth. Several studies investigated the determinants of FDI inflows and some of them concentrated on the role of human capital. According to Assuncao et al. (2011), existing literature showed three main determinants of FDI: location (infrastructure, human capital, and so on), institutions (corruption, political instability, and so on) and factors related to trade theory (openness, factor endowments, and so on). The present study focused on human capital. In addition to allowing countries to take better advantage of technological diffusion, existing literature showed that the level of human capital could affect the attractiveness of countries with respect to FDI.

The evidence of the relationship between human capital and FDI remains mixed. On one hand, human capital is one of the determinants for the location of FDI flows. This relationship is demonstrated in many empirical studies in the literature. For instance, Brooks et al. (2010) showed that human capital positively affects FDI inflows, especially in skilled labor intensive sectors where the level of education could allow technological innovation and productivity improvement. Noorbakhsh et al. (2001) found that human capital is one of the key determinants of FDI inflows and the effect increases over time. On the other hand, other empirical findings revealed that there is no effect of human capital on FDI flows. For instance, Root and Ahmed (1978) found that human capital is not a determinant for FDI. In the same vein, Narula (1996) pointed out that even though human capital comes up with a positive sign in the econometric model, it is not a significant determinant of FDI inflows. Using a secondary education index to proxy the level of human capital, Cleeve (2008) revealed that the relationship between FDI and the human capital level is not conclusive. Cheng and Kwan (2000), using China's regional level data, showed that the quality of labor, in a variety of measures, is insignificant in explaining the regional distribution of FDI in China. Hong (2008) found an insignificant impact of labor quality on the location of China's inward-FDI. More recently, Cleeve, Debrah and Yiheyis (2015) found that there is no evidence of the importance of human capital for FDI inflows to Sub-Saharan Africa.

The current paper explores new evidence regarding the relationship between human capital and FDI inflows. Special attention is given to the role of education adequacy rather than the level of education. Quoting Psacharopoulos (1986), Dumartin (1997), Smith (2001), Melitz (2003) and Vincens (2005), the adequacy of the education system to the labor market could be defined as a process aiming to provide the economy with the optimal quantity of qualified labor. As the component of this broader concept, the external efficiency of the education system captures the efficiency with which the years of schooling are translated into income in the labor market. This research investigates the role of the external efficiency of the education system in FDI attractiveness. 


\section{Methodology \\ A. External efficiency of education and FDI: a formalization}

A model of a small open developing economy producing a composite good at each period, $t$ is proposed. Constant returns to scale production technology is assumed and this could be captured by a Cobb-Douglas production function as follows:

$Y_{t}=A\left(q_{t}\right) K_{t}^{1-\alpha} L_{t}^{\alpha}$

$L_{t}$ is the stock of labor, $K_{t}$ is the stock of capital, $0<\alpha<1$ is the Cobb-Douglas parameter and $A\left(q_{t}\right)=A_{0} q_{t}$ is the total factor productivity (TFP). The latter depends positively on the external efficiency of the education system denoted by $q_{t}$ and a scale parameter $=A_{0}$ with $0<q_{t}<1$. It is assumed that education enhances labor productivity (Schultz, 1961, Denison, 1962 and Lucas, 1998). In addition, there is a hypothetical perfect productivity level given by $A_{0}$ and deviations from this maximum productivity level is caused by some inefficiencies in the education system. A higher value of $q_{t}$ implies a higher level of the efficiency with which education is translated into income in the labor market. The first order conditions with respect to production factors $K_{t}$ and $L_{t}$ lead to the rate of return $\left(r_{t}\right)$ and the salary level $\left(w_{t}\right)$ respectively:

$r_{t}=(1-\alpha) A_{0} q_{t} k_{t}^{-\alpha}$

$w_{t}=-\alpha A_{0} q_{t} k_{t}^{1-\alpha}$

with $k_{t}$ denoting the capital to labor ratio $K_{t} / L_{t}$.

The economy is open and capital is mobile internationally. However, international capital flows are such that the domestic interest rate is equal to the international interest rate augmented by a country-risk premium: $r_{t}=r_{t}^{*}+\pi_{t} . \pi_{t}$ is related to internal factors such as, political instability, corruption, individual freedom, degree of trade liberalization, quality of governance, and so on. Equation 2 gives the capital-to-labor ratio equation:

$k_{t}=\left[\frac{(1-\alpha) A_{0} q_{t}}{r_{t}^{*}+\pi_{t}}\right]^{\frac{1}{\alpha}}$

Using equations (3) and (4) yields:

$$
k_{t}=\alpha\left(A_{0} q_{t}\right)^{\frac{1}{\alpha}}\left[\frac{(1-\alpha)}{r_{t}^{*}+\pi_{t}}\right]^{\frac{1-\alpha}{\alpha}}
$$


with the derivatives $k_{q}>0$ and $w_{q}>0 .^{2}$

The stock of capital in the economy at the equilibrium is given by:

$K_{t}=k_{t} * L_{t}=\left[\frac{(1-\alpha) A_{0} q_{t}}{r_{t}^{*}+\pi_{t}}\right]^{\frac{1}{\alpha}} \lambda_{t} L_{t}$

The stock of capital could be shared between the domestic component $\overline{K_{t}}$ and the foreign component $K_{t}^{*}$ so that $K_{t}=\overline{K_{t}}+K_{t}^{*}$ with $K_{t}^{*}=K_{t-1}^{*}+F D I_{t}$ and $\overline{K_{t}}=\overline{K_{t-1}}+\overline{I_{t}}$, where $\overline{I_{t}}$ is the domestic investment. We have $K_{t}=\overline{K_{t-1}}+I_{t}+K_{t-1}^{*}+F D I_{t}$. Let's denote this by $\lambda_{t}$, the proportion of the FDI in the stock of capital, so that $\frac{K_{t}}{F D I_{t}}=\frac{1}{\lambda_{t}}$.

The relationship between $K_{t}$ and $F D I_{t}$ is given by $F D I_{t}=\lambda_{t} K_{t}$ leading to the following equation:

$F D I_{t}=\left[\frac{(1-\alpha) A_{0} q_{t}}{r_{t}^{*}+\pi_{t}}\right]^{\frac{1}{\alpha}} \lambda_{t} L_{t}$

$F D I_{t}$ is the net inflows of foreign direct investment at time $t$.

Equation (7) describes the relationship between the external efficiency of the education system and FDI. The first implication is that both, stock of the labor force and efficiency level of the education system have a positive impact on FDI. Perfect efficiency means that the workers are perfectly efficient in translating their education level into income in the economy. They could generate the highest level of production compared to their level of education with no possibility of doing better with the same level of education. This relationship is intuitive because a higher efficiency level is associated with higher productivity of the labor force and this could in turn attract foreign investors looking for countries with productive labor force. Second, the foreign interest rate, as well as factors related to country-risk has a negative impact on the FDI. An increase in the international interest rates may undermine the investment made by foreign investors. The model shows that the intensity of the capital in the production process captured by $(1-\alpha)$ has a positive relationship with FDI inflows. The latter result means that countries with a higher demand for capital in the production process would better attract FDI, all things being equal.

\footnotetext{
${ }^{2}$ The intuition behind these derivatives is that since a higher external efficiency of the education system could induce a higher productivity of the labor, the wage level increases with the level of efficiency. Given a higher labor productivity level, the economy needs a smaller level of labor per unit of capital.
} 


\section{B. Econometric strategy}

From the formalization above, consider a set of $M$ variables $x_{m}$ with $m=1, \ldots M$; We could give the following functional form to the interest rate: $r_{t}=r_{t}^{*}+\pi_{t}=\exp \left(\sum_{m} \beta_{m} x_{m}+u\right)$. $\beta$ is a set of parameters, $x$ is a matrix containing proxy variables for the country-risk and the international interest rate and $u$ is a random variable capturing stochastic shocks on the interest rate. The idea underlying this functional form is that the cost associated to risks -the interest rate- is increasing more rapidly with respect to risk factors. ${ }^{3}$ Log-linearizing Equation 7 yields equation 8 :

$\log \left(\frac{F D I_{i t}}{L_{i t}}\right)=\frac{1}{\alpha} \log \left[(1-\alpha) A_{0}\right]+\frac{1}{\alpha} \log \left(q_{i t}\right)-\frac{1}{\alpha}\left(\sum_{m} \beta_{m} x_{i t m}+u_{i t}\right)+\log \left(\lambda_{i t}\right)$

By assuming $f d i_{i t}=\log \left(\frac{F D I_{i t}}{L_{i t}}\right), \theta_{0}=\frac{1}{\alpha} \log \left[(1-\alpha) A_{0}\right], \theta_{1}=\frac{1}{\alpha}$ and $\theta_{2 m}=-\frac{1}{\alpha} \beta_{m}, v_{i t}=$ $-\frac{1}{\alpha} u_{i t}+\log \left(\lambda_{i t}\right)$, the following econometric model can be derived and be estimated:

$f d i_{i t}=\theta_{0}+\theta_{1} \log \left(q_{i t}\right)+\sum_{k} \theta_{2 m} x_{i t m}+v_{i t}$

with $q_{i t}$ a proxy for the external efficiency of the education system for the country $i$ at time $t$.

\section{External efficiency of the education system}

It is assumed that there is a maximum level of income that a given skilled worker could expect given the number of years of schooling and the economic environment. The gap between the actual income and this optimal income approximates the efficiency with which education is translated into income in the labor market. The smaller this gap is, the more efficient is the hypothetical worker. In fact, perfect external efficiency implies that the skills acquired in the education system perfectly fit the demand for skilled workers. When this condition is met, the combination of years of schooling and income earned on the labor market is optimal and efficient.

The main assumption in the estimation of the external efficiency of the education system is related to the existence of a frontier representing the maximum income that the population of a given country could reach with the attained level of education. In other terms, we would like to build a frontier of best practices in terms of translating the years of schooling into income. Countries lying on the frontier are technically efficient while those below the frontier are considered technically inefficient. The distance to this frontier is used as proxy for the external efficiency of the education system.

In the literature on frontier analysis, two main approaches are commonly used in order to

\footnotetext{
${ }^{3}$ The assumption here is related to a risk aversion hypothesis: given an increase in the risk level, economic agents claim higher than proportional interest payment.
} 
build production frontiers and estimate technical efficiency: non-parametric and parametric approaches. The non-parametric approaches do not allow the distinction between the efficiency measure and the 'noises', while some parametric models allow proper estimation of the technical efficiency. Stochastic Frontier Analysis (SFA) is among the most commonly used parametric approaches. It allows the estimation of efficiency terms, controlling not only for 'noises' but also for defined environmental factors that can influence the efficiency measure.

This study applied a Stochastic Frontier model in order to estimate a proxy for the external efficiency of the education system. It is assumed that the input (measured by the mean years of schooling) is used to generate the output (measured by the labor remuneration). Let us define the output variable by $L A B I N C_{i t}$, that is, the labor remuneration in the country $i$ at time $t$ proxied by the GNI per unit of employment, and $\eta$ as a set of parameters. Following Battese and Coelli (1995), and by assuming a Cobb Douglas function for the frontier, the SFA model that will be estimated is the following: ${ }^{4}$

$\log \left(L A B I N C_{i t}\right)=\eta_{0}+\eta_{1} \log \left(M Y S_{i t}\right)+u_{i t}-\omega_{i t}$

where $M Y S_{i t}$ is the mean years of schooling in the country $i$ at time $t . \omega$ is the technical inefficiency term that has a normal truncated distribution and $\mu$ is the error terms that are normally distributed. The Battese and Coelli (1995) model allows the inefficiency terms to vary over time. Another specificity of this model is that $\omega_{i t}$ could be considered random time varying individual effects. Unobserved heterogeneity between countries is controlled for.

It is important to isolate the technical inefficiency terms from other variables that could be associated with them. Otherwise, the value of the efficiency measure could be imperfect. So, in the efficiency measurement, other economic variables that could affect the efficiency are controlled for. Two main explanatory factors are considered: factor associated with the labor market (the employment rate) and control variables for regions. The inefficiency model is given by Equation 11 as follows:

$\omega_{i t}=Z_{i t} \gamma+v_{i t}$

where the distribution of $v_{i t}$ is normal truncated. $Z_{i t}$ is a matrix of explanatory variables that could explain the inefficiency terms. After controlling for the inefficiency explanatory factors, the technical efficiency (the proxy for the external efficiency of the education system) is given by:

$q_{i t}=\exp \left(-\omega_{i t}\right)=\exp \left(Z_{i t} \gamma+v_{i t}\right)$

\footnotetext{
${ }^{4}$ Two functional forms are generally used for the frontier: Cobb Douglas and Translog functions. In this paper, a Translog function is first estimated and some key parameters are not significant (the parameters associated with the quasi-convexity of the frontier function). The Cobb Douglas function is convenient for the frontier. Recall that the Cobb Douglas function is a special case of the Translog functional form, when the quasiconvexity assumption is relaxed.
} 


\section{DATA}

As mentioned, LABINC proxies the income generated by a unit of labor in a given country. It is calculated using the GNI per capita and estimates of the share of the labor remuneration in the total value added based on social accounting matrices provided by Trapp (2015). Trapp (2015) built a labor share dataset for a set of countries covering the period 1988-2010 for the countries included in the sample of this study. Information on the labor share in the value added is used with the GNI figures to calculate estimates of the labor remuneration. This output variable reflects what the labor force generates in terms of income. The mean years of formal schooling is used as input capturing the workers' number of years of schooling. As factors that could explain the inefficiency, we use variables that control for the labor market and for the regions. ${ }^{5}$

Table 1 gives descriptive statistics of all the variables used to estimate the external efficiency of the education system (Panel A). Data used were collected from the World Bank's World Development Indicators database and from Trapp (2015). Overall, about 45 percent of the GNI is generated from the remuneration of labor. The coefficient of variation of the input is higher than that of the output indicating that there are higher heterogeneities across countries in the output than there is in the input. This implies that with the same level of education, countries may be able to reach different levels of labor remuneration. Estimation of the efficiency with which the years of schooling is translated into labor income can help identify countries with higher performance.

Panel B shows the data used to estimate Equation 9. External efficiency of the education system, estimated from the stochastic frontier model, is used as the main explanatory factor for the FDI net inflows. FDI data, as well as the data used for the control variables are collected from WDI.

\footnotetext{
${ }^{5}$ The choice of variables here is constrained by data availability. The use of education data significantly reduces the sample size. For this reason, a regression with controls for education data is only used in order to investigate the drivers for the external efficiency of the education system.
} 


\begin{tabular}{|c|c|c|c|c|}
\hline & Mean & $\begin{array}{l}\text { Standard } \\
\text { Deviation }\end{array}$ & Maximum & Minimum \\
\hline \multicolumn{5}{|l|}{ Panel A: Efficiency model } \\
\hline \multicolumn{5}{|l|}{ Output } \\
\hline GNI per person employed & 4823.8 & 4008.9 & 122.5 & 20345.6 \\
\hline \multicolumn{5}{|l|}{ Inputs } \\
\hline Mean years of schooling & 7.4 & 2.6 & 0.9 & 13.1 \\
\hline \multicolumn{5}{|l|}{ Explanatory factors for the inefficiency } \\
\hline Primary school starting age & 6.3 & 0.6 & 5.0 & 8.0 \\
\hline \multicolumn{5}{|l|}{ Secondary education vocational pupils (percent of total } \\
\hline Employment rate & 55.5 & 10.5 & 29.8 & 81.8 \\
\hline \multicolumn{5}{|l|}{ Panel B: FDI model } \\
\hline \multicolumn{5}{|l|}{ Key variables } \\
\hline FDI net inflows per unit of employment (constant 2000 US \$) & 305.7 & 471.2 & -202.6 & 4144.6 \\
\hline External efficiency of the education system & 0.4 & 0.3 & 0.0 & 1.0 \\
\hline \multicolumn{5}{|l|}{ Control variables } \\
\hline \multicolumn{5}{|l|}{ Infrastructure } \\
\hline Telephone lines (per 100 people) & 14.8 & 11.4 & 0.0 & 43.6 \\
\hline \multicolumn{5}{|l|}{ Institutions } \\
\hline Regulation quality & -0.1 & 0.7 & -1.7 & 1.5 \\
\hline Voice and accountability & -0.2 & 0.8 & -1.9 & 1.2 \\
\hline \multicolumn{5}{|l|}{ Openness and international interest rate } \\
\hline Exports (percent of GDP) & 38.1 & 16.7 & 6.7 & 98.8 \\
\hline Average interest on new external debt commitments, official & 2.9 & 1.9 & 0.0 & 8.8 \\
\hline Average interest on new external debt commitments, private & 3.4 & 3.2 & 0.0 & 12.8 \\
\hline \multicolumn{5}{|l|}{ Other economic control variables } \\
\hline GDP growth & 4.8 & 3.9 & -14.8 & 18.9 \\
\hline Inflation (GDP deflator) & 8.9 & 9.9 & -14.0 & 138.0 \\
\hline
\end{tabular}

\section{Results}

\section{A. Estimate of external efficiency}

Table 2 presents the results of the estimation of the external efficiency of the education system. ${ }^{6}$ Three different models are estimated for a robustness check purpose. Model 3 controls for the education and the labor market variables while Model 2 controls only for the labor market variables. Model 1 does not control for any of the two sets of variables. In all these three specifications, results show a positive relationship between the years of schooling and labor income. Countries with a higher primary school starting age and a larger proportion of adults involved in the labor market appear to have a higher inefficiency level. ${ }^{7}$ Countries with a higher share of vocational pupils in secondary education, as well as a higher

\footnotetext{
${ }^{6}$ A negative coefficient in the inefficiency model means that the considered variable is negatively linked to the inefficiency level.

${ }^{7}$ The latter result could be counter-intuitive. countries' labor supply is dominated by unskilled labor. A higher employment rate is an indication that the labor market tends to absorb low-skilled labor force, which is associated with a lower remuneration per unit of employment and a higher inefficiency.
} 
enrollment rate in tertiary education appear to have a lower inefficiency level. Secondary vocational education and tertiary education could play a role in improving the external efficiency of the education system in the target countries. In the literature, both secondary vocational education and tertiary education are pointed out to be among the most important drivers for the external efficiency of education. For instance, McMahon and Boediono (1992) showed that imperfection in the financing of post primary education could explain the external inefficiency of the education system. Almeida, Behrman and Robalino (2012) highlighted that promoting secondary vocational training is one of the ways countries could provide the right skills for their labor market.

Table 2: Stochastic Frontier Model: External Efficiency of the Education System

\begin{tabular}{|c|c|c|c|}
\hline Dependent Variable: Labor income & Model 1 & Model 2 & Model 3 \\
\hline \multicolumn{4}{|l|}{ Frontier model } \\
\hline Intercept & $\begin{array}{c}9.866^{* * *} \\
(0.098)\end{array}$ & $\begin{array}{r}10.116^{\star * *} \\
(0.185)\end{array}$ & $\begin{array}{r}10.785^{* * *} \\
(0.240)\end{array}$ \\
\hline Mean years of schooling & $\begin{array}{c}1.272^{* * *} \\
(0.050)\end{array}$ & $\begin{array}{r}1.145^{\star * *} \\
(0.088)\end{array}$ & $\begin{array}{r}0.804^{* * *} \\
(0.108)\end{array}$ \\
\hline \multicolumn{4}{|l|}{ Inefficiency model } \\
\hline Employment to population ratio $(15+)$ & & $\begin{array}{r}0.064^{* * *} \\
(0.011)\end{array}$ & $\begin{array}{l}0.024^{* *} \\
(0.010)\end{array}$ \\
\hline Primary school starting age & & & $0.468^{* * *}$ \\
\hline Secondary education vocational pupils (in percent of total pupil & & & $\begin{array}{r}-0.041^{* * *} \\
(0.007)\end{array}$ \\
\hline Gross tertiary enrolment rate & & & $\begin{array}{r}-0.040^{* * *} \\
(0.006)\end{array}$ \\
\hline Intercept & $\begin{array}{c}0.830 * * \\
(0.385)\end{array}$ & $\begin{array}{r}-2.245^{\star * *} \\
(0.242)\end{array}$ & $\begin{array}{r}-1.720 \\
(1.130)\end{array}$ \\
\hline Regions dummies & Yes & Yes & Yes \\
\hline Observations & 618 & 615 & 352 \\
\hline Countries & 79 & 79 & 55 \\
\hline
\end{tabular}

Note: *significant at 10 percent; ${ }^{* *}$ significant at 5 percent; ${ }^{* * *}$ significant at 1 percent.

The average technical efficiency is estimated to be about 44 percent. $^{8}$ This means that countries could use, on average, 66 percent fewer inputs to achieve the same level of labor remuneration if the education system in all countries was perfectly efficient. Alternatively, with the actual education resources used, countries could achieve higher levels of income. These results show that the inefficiency level seems to be relatively high. Table 3 shows that the efficiency level varies across regions. While Latin America and the Caribbean, as well as

\footnotetext{
${ }^{8}$ Model 3 is a complete model because it controls for the maximum number of inefficiency factors. However, due to the limited number of Observations in Model 3, Model 2 is used to estimate the technical efficiency scores.
} 
Middle East and North Africa appear to register the highest average efficiency levels, SubSaharan Africa and South Asia have the lowest average efficiency. ${ }^{9}$

Table 3: External Efficiency by Region (in percent)

\begin{tabular}{lrrr}
\hline & Average & Minimum & Maximum \\
\hline South Asia & 18.0 & 24.0 & 34.0 \\
Sub-Saharan Africa & 2.0 & 36.0 & 80.0 \\
East Asia and Pacific & 8.0 & 37.0 & 79.0 \\
Europe and Central Asia & 1.0 & 38.0 & 91.0 \\
Middle East and North Africa & 20.0 & 48.0 & 95.0 \\
Latin America & 18.0 & 61.0 & 94.0 \\
\hline
\end{tabular}

\section{B. Impact of external efficiency on FDI}

Equation 9 is estimated using the data described above and including a set of control variables as indicated by the matrix $x$. According to Assuncao et al. (2011), there are three main factors that could affect FDI flows in a given country: factors related to the localization, factors related to institutions and factors related to openness. We controlled for these factors by including appropriate variables in the matrix $x$. Econometric results are shown in Table 4. Equation 9 is first estimated by applying a pooled OLS model (Model 1) and a fixed effects model (Model 2). The pooled OLS estimations showed a positive relationship between the external efficiency of the education system and the FDI net inflows per unit of employment. To account for the panel structure of the data and control for individual heterogeneity, a fixed effects estimation is performed on the Equation 9. The fixed effects model suggested a positive relationship between the education efficiency and the FDI inflows ${ }^{10}$.

In the literature on the determinant of FDI, some studies suggested that past FDI flows could affect present FDI flows (Egger, 2001; Carstensen and Toubal, 2004; Naude and Krugell, 2007). For this reason, dynamic equations were sometimes estimated to investigate the determinants of FDI. Authors of literature found that FDI flows in a given country could have an impact on a country's educational achievements (Blomstrom and Kokko, 2003; Zhuang, 2008; Mughal and Vechiu, 2010). This may induce a reverse causality between the external efficiency of education and the FDI inflows raising an endogeneity issue. To properly control for this endogeneity problem and include FDI lags in the matrix $x$, we implemented the dynamic panel GMM estimation technique introduced by Arellano and Bond (1991) and Arellano and Bover (1995). This method controls for endogeneity by using lags of the endogenous variables as instruments in the econometric equation and controls for autocorrelation issues that could appear after introducing lags of the dependent variable as

\footnotetext{
${ }^{9}$ Appendix 1 provides the average efficiency score by country.

${ }^{10} \mathrm{~A}$ Haussman specification test shows that the fixed effects model is preferred to the random effects model
} (continued...) 
regressors. We assume that FDI inflows could affect economic growth and openness. ${ }^{11}$ Thus, we control for the endogeneity associated with these two variables using the lags of these endogenous regressors as instruments. ${ }^{12}$

As shown in Table 4, results from Arellano and Bover (1995) dynamic panel GMM estimation showed that after controlling for the endogeneity of the external efficiency of the education system variable and including lag of the FDI on the right side of Equation 9, education efficiency remained a significant determinant for FDI flows. All these results are robust after controlling for any category of the FDI determinants, as described above; and the education efficiency remains a significant determinant of FDI net inflows. ${ }^{13}$ After controlling for localization, institutions and openness, results (for Model 3) suggested an increase of about 0.4 percent in the FDI net inflow per unit of employment after a 1 percent improvement in the efficiency level. Equivalently, one standard deviation increase in the efficiency level is associated with 24 percent increase in the FDI net inflow per unit of employment. These results suggest that improving the efficiency of the education system, by giving the appropriate abilities to workers according to the requirements of the economy, could be a way for improving the attractiveness of countries with regard to foreign investments. Other variables such as, economic growth, infrastructure, openness and the quality of the institutions appear to have statistically significant effects on the FDI.

Another regression is performed applying dynamic panel model to investigate the relationship between FDI and the years of schooling (Model 4). The results showed no significant effect of the years of schooling on the FDI net inflows. This finding supports the evidence that the number of years of schooling does not necessarily have an effect on FDI. However, the efficiency with which the education level is used in the labor market matters for attracting FDI. We investigate the joint effect of the mean years of schooling and the education efficiency variable and find that these two variables together have a significant effect on FDI inflows (Model 5). The joint effect of the years of schooling and the efficiency of the education system on the FDI is stronger compared to the effect of the external efficiency of the education system only. Improving both the years of schooling and the efficiency of the education system could play an important role in attracting FDI.

\footnotetext{
${ }^{11}$ A given country could have a higher economic growth because of the economic activity that the FDI flows would cause. FDI could contribute in developing some activities that require more exchange with the rest of the world.

${ }^{12}$ We could add other instruments in addition to variable lags but the main constraint is the unavailability of data for some relevant instruments that could have used.

${ }^{13}$ Hansen's test for over-identifying restrictions confirms that instruments are valid. We implement a test for zero autocorrelation in first-differenced errors. Results showed that there is no evidence of model misspecification.
} 
Table 4: External Efficiency and FDI: Econometric Results

\begin{tabular}{|c|c|c|c|c|c|}
\hline Dependent Variable: FDI inflows & Model 1 & Model 2 & Model 3 & Model 4 & Model 5 \\
\hline & Pooled OLS & Fixed Effects & GMM & GMM & GMM \\
\hline \multicolumn{6}{|l|}{ Key variables } \\
\hline Log FDI per worker (t-1) & & & $\begin{array}{r}0.585^{\star * *} \\
(0.090)\end{array}$ & $\begin{array}{c}0.633^{* * *} \\
(0.111)\end{array}$ & $\begin{array}{r}0.537)^{* * *} \\
(0.151)\end{array}$ \\
\hline External efficiency of education & $\begin{array}{r}0.317^{* * *} \\
(0.074)\end{array}$ & $\begin{array}{l}1.497^{* *} \\
(0.682)\end{array}$ & $\begin{array}{l}0.393^{* *} \\
(0.152)\end{array}$ & & \\
\hline External efficiency of education $\times$ Mean years of schooling & & & & & $\begin{array}{l}0.420^{* *} \\
(0.207)\end{array}$ \\
\hline Mean years of schooling & & & & $\begin{array}{c}-0.338 \\
(0.426)\end{array}$ & \\
\hline \multicolumn{6}{|l|}{ Infrastructure } \\
\hline Telephone lines & $\begin{array}{r}0.057^{* * *} \\
(0.005)\end{array}$ & $\begin{array}{r}0.070^{* * *} \\
(0.025)\end{array}$ & $\begin{array}{l}0.018^{\star *} \\
(0.008)\end{array}$ & $\begin{array}{r}0.025 \\
(0.016)\end{array}$ & $\begin{array}{r}0.014 \\
(0.011)\end{array}$ \\
\hline \multicolumn{6}{|l|}{ Institutions } \\
\hline Regulation quality & $\begin{array}{r}1.327^{* * *} \\
(0.133)\end{array}$ & $\begin{array}{r}1.259 \\
(0.759)\end{array}$ & $\begin{array}{r}0.480 \text { ** } \\
(0.197)\end{array}$ & $\begin{array}{l}0.557^{* *} \\
(0.223)\end{array}$ & $\begin{array}{c}0.393^{*} \\
(0.216)\end{array}$ \\
\hline Voice and accountability & $\begin{array}{r}-0.518^{* * *} \\
(0.104)\end{array}$ & $\begin{array}{r}-0.418 \\
(0.509)\end{array}$ & & $\begin{array}{r}-0.081 \\
(0.144)\end{array}$ & $\begin{array}{c}-0.167 \\
(0.149)\end{array}$ \\
\hline \multicolumn{6}{|l|}{ Openness and international interest rate } \\
\hline Exports (percent of GDP) & $\begin{array}{r}0.013^{* * *} \\
(0.004)\end{array}$ & $\begin{array}{r}0.01 \\
(0.009)\end{array}$ & $\begin{array}{c}0.015^{*} \\
(0.008)\end{array}$ & $\begin{array}{l}0.021^{* *} \\
(0.008)\end{array}$ & $\begin{array}{l}0.019 * * \\
(0.009)\end{array}$ \\
\hline Official interest on new external debt commitments & $\begin{array}{r}0.128^{* * *} \\
(0.033)\end{array}$ & $\begin{array}{r}0.03 \\
(0.036)\end{array}$ & $\begin{array}{c}-0.001 \\
(0.027)\end{array}$ & $\begin{array}{r}0.031 \\
(0.029)\end{array}$ & $\begin{array}{r}0.039 \\
(0.030)\end{array}$ \\
\hline Private interest on new external debt commitments & $\begin{array}{r}-0.058^{* * *} \\
(0.020)\end{array}$ & $\begin{array}{r}-0.024 \\
(0.023)\end{array}$ & $\begin{array}{r}0.001 \\
(0.019)\end{array}$ & $\begin{array}{r}-0.037 \\
(0.051)\end{array}$ & $\begin{array}{r}-0.098^{* *} \\
(0.047)\end{array}$ \\
\hline \multicolumn{6}{|l|}{ Other control variables } \\
\hline Inflation (GDP deflator) & $\begin{array}{r}0.035)^{* * *} \\
(0.008)\end{array}$ & $\begin{array}{c}0.022^{*} \\
(0.012)\end{array}$ & $\begin{array}{c}0.029 * \\
(0.016)\end{array}$ & $\begin{array}{r}0.018 \\
(0.013)\end{array}$ & $\begin{array}{r}0.012 \\
(0.017)\end{array}$ \\
\hline GDP growth & $\begin{array}{r}0.008 \\
(0.017)\end{array}$ & $\begin{array}{r}0.022 \\
(0.019)\end{array}$ & $\begin{array}{l}0.048^{* *} \\
(0.021)\end{array}$ & $\begin{array}{c}0.066^{\star * *} \\
(0.024)\end{array}$ & $\begin{array}{l}0.054^{* *} \\
(0.023)\end{array}$ \\
\hline Intercept & $\begin{array}{r}3.426^{* * *} \\
(0.227)\end{array}$ & $\begin{array}{r}4.967^{* * *} \\
(1.067)\end{array}$ & $\begin{array}{l}1.189 * * \\
(0.555)\end{array}$ & $\begin{array}{r}0.964 \\
(0.971)\end{array}$ & $\begin{array}{r}0.907 \\
(0.748)\end{array}$ \\
\hline Time dummies & Yes & Yes & Yes & Yes & Yes \\
\hline F-stat & $p=0.000$ & $p=0.000$ & $p=0.000$ & $p=0.000$ & $p=0.000$ \\
\hline R2 & 0.611 & .. & .. & .. & .. \\
\hline Observations & 368 & 368 & 368 & 368 & 368 \\
\hline Sargan test of overidentication restrictions & .. & .. & $p=0.630$ & $p=0.389$ & $p=0.602$ \\
\hline Arellano-Bond test for $\mathrm{AR}(1)$ & .. & .. & $p=0.001$ & $p=0.001$ & $p=0.001$ \\
\hline Arellano-Bond $\mathrm{AR}(2)$ & .. & .. & $p=0.162$ & $p=0.160$ & $p=0.147$ \\
\hline Countries & 59 & 59 & 59 & 59 & 59 \\
\hline
\end{tabular}

\section{Extensions: sample heterogeneity}

Table 5 shows that the effect of the external efficiency of the education system on FDI inflows varies across groups of countries depending on their geographical characteristic (e.g. landlocked), Human Development Index (HDI), income level, endowment in natural resources, external efficiency score, and FDI inflows. ${ }^{14}$ The results show that the external

${ }^{14}$ Countries are considered resource rich when the total resource rents as a percentage of the GDP is above the median and non-resource rich when the total resource rents as a percentage of the GDP is below the median. Countries are grouped according to the 2010 Human Development Report which classifies countries into four categories (low, medium, high and very high human development levels) based on the Human Development Index. 
efficiency of the education system matters in non-landlocked countries, in non-resource rich countries, in countries with low development levels (HDI and income levels), and in countries with low efficiency score and low FDI inflows. The external efficiency of the education system does not necessarily attract FDI in landlocked countries but it could do so in non-landlocked countries. The external efficiency of the education system does not have any effect on FDI in the group of countries with high and very high human development levels. However, one standard deviation increase in the efficiency score is associated with 14 percent in the FDI per unit of employment in countries belonging to the group of low and medium human development levels. In a similar vein, the external efficiency of the education system has an effect on FDI inflows in countries with low GDP per capita. There is a significant relationship between FDI and the external efficiency of education in non-resource rich countries while this relationship is not statistically significant in resource rich countries. One standard deviation increase in the efficiency score is associated with 24 percent increase in the FDI inflows in non-resource rich countries. In fact, some studies show that resource rich countries have a higher potential to attract FDI (Cleeve, et al 2015 and Van der Ploeg and Poelhekke, 2016) compared to non-resource rich countries. The current results support the evidence that non-resource rich countries can fill the gap in terms of FDI attractiveness by improving the external efficiency of their education systems. Efficiency and FDI inflows levels also count. FDI attractiveness is stronger when efficiency and FDI inflows are low.

Table 5: External Efficiency and FDI (additional results) Dependent variable: FDI inflows

\begin{tabular}{|c|c|c|c|c|}
\hline \multicolumn{5}{|c|}{ Model 4 (GMM) } \\
\hline \multicolumn{2}{|l|}{ Characteristics } & \multicolumn{2}{|c|}{ External efficiency of education } & Observations \\
\hline \multirow[t]{2}{*}{ Landlocked } & Yes & $0.187^{\prime \prime}$ & $(0.108)$ & 67 \\
\hline & No & $0.431^{* \prime}$ & $(0.218)$ & 301 \\
\hline \multirow[t]{2}{*}{ Resource rich } & Yes & $0.221^{\prime}$ & $(0.157)$ & 178 \\
\hline & No & $0.389 * *$ & $(0.142)$ & 190 \\
\hline \multirow[t]{2}{*}{ Human Development Index } & Low & $0.225^{*}$ & $(0.113)$ & 192 \\
\hline & High & $0.084^{\prime}$ & $(0.249)$ & 176 \\
\hline \multirow[t]{2}{*}{ GDP per capita } & Below median & $0.329 * *$ & $(0.123)$ & 203 \\
\hline & Above median & $0.200^{\prime}$ & $(0.244)$ & 165 \\
\hline \multirow[t]{2}{*}{ Efficiency score } & Below median & $0.527^{* * *}$ & $(0.123)$ & 207 \\
\hline & Above median & $0.070^{\top}$ & $(0.497)$ & 161 \\
\hline \multirow[t]{2}{*}{ FDI inflows } & Below median & $0.269^{* \prime}$ & $(0.134)$ & 172 \\
\hline & Above median & $-0.037^{\prime \prime}$ & $(0.165)$ & 196 \\
\hline
\end{tabular}

Note: Countries are considered resource rich when the total resource rents as a percentage of the GDP is above the median and non-resource rich when the total resource rents as a percentage of the GDP is below the median. Countries are also grouped according to the 2010 Human Development Report which classifies countries into four categories (low, medium, high and very high human development levels) based on the Human Development Index. All controls variables (infrastructure institutions, openness, interest rate) are included. Standard deviation in parenthesis. * ${ }^{*}$ ignificant at 10 percent; ${ }^{* *}$ significant at 5 percent; ${ }^{* * *}$ significant at 1 percent. 


\section{Conclusion}

This research examined the relationship between the external efficiency of the education system and FDI inflows. The external efficiency of the education system is estimated using a stochastic frontier model. We find that both vocational secondary education and the enrollment rate in higher education appear to be negatively associated with the inefficiency level. This result suggests that vocational secondary education and tertiary education could play a role in improving the external efficiency of the education system. Our results support the evidence that the external efficiency of the education system has a positive effect on FDI, while the years of schooling alone do not have any impact on FDI inflows. This means that the capacity for the labor force to translate properly its education into income in the labor market seems to be more important than the level of education itself, in attracting FDI. However, the external efficiency of the education system and the years of schooling have a positive joint effect on FDI inflows. Moreover, countries with low human development levels as well as non-resource rich countries have a higher potential to attract FDI by improving the external efficiency of their education systems. In particular, there is room for non-resource rich countries to fill the gap in terms of FDI attractiveness by building quality education systems with a special focus on the needs of the economic activities. Furthermore, it appears from the findings that countries could enhance their attractiveness with respect to FDI by implementing target policies in the post-primary education system leading to an increased access to secondary vocational training and higher education. For instance, improving the access and the quality of specific programs in secondary vocational and technical education and in higher education could be a way to increase countries' attractiveness, with respect to FDI. However, the paper does not identify the fields of study that could be important for the external efficiency of the education system. It would be interesting to further investigate which fields of study in the secondary education system are more relevant to better attract foreign investments. 


\section{REFERENCES}

Almeida, R. Behrman, J. and Robalino, D. (2012). The Right Skills for the Job? Rethinking Training Policies for Workers. The World Bank Group.

Arellano, M. and Bond, S. (1991). Some Tests of Specification for Panel Data: Monte Carlo Evidence and an Application to Employment Equations. Review of Economic Studies, 58(2): 277-297.

Arellano, M. and Bover, O. (1995). Another look at the instrumental variable estimation of error-components models. Journal of Econometrics, 68(1): 29-51.

Assuncao, S., Forte, R. and Teixeira, A. A. C. (2011). Location Determinants of FDI: A Literature Review, FEP Working Papers No 433.

Battese, G. E. and Coelli, T. J. (1995). A Model for Technical Inefficiency Effects in a Stochastic Frontier Production Function for Panel Data. Empirical Economics, 20(2): 325332.

Battese, G.E. and Coelli, T.J. (1993). A stochastic frontier production function incorporating a model for technical inefficiency effects. Working Papers in Econometrics and Applied Statistics No 69, Department of Econometrics, University of New England, Armidale.

Blomstrom, M. and Kokko, A. (2003). Human capital and inward FDI. Working Papers Series, No. 167, The European Institute of Japanese Studies (Stockholm School of Economics, Sweden).

Borensztein, E., De Gregorio, J. and Lee, J. (1998). How Does Foreign Direct Investment Affect Economic Growth? Journal of International Economics, 45: 115-135.

Brooks, D. H., Hasan, R., Lee, J.-W., Son, H. H. and Zhuang, J. (2010). Closing

Development Gaps: Challenges and Policy Options. Asian Development Review, 27(2): 1-28.

Bwalya, M. S. (2006). Foreign direct investment and technology spillovers: Evidence from panel data analysis of manufacturing firms in Zambia. Journal of Development Economics, 81(2): 514-526.

Carstensen, K. and Toubal, F. (2004). Foreign direct investment in Central and Eastern European countries: A dynamic panel analysis. Journal of Comparative Economics, 32(1): 322.

Cheng, K. L. and Kwan, K. Y. (2000). What are the determinants of the location of foreign direct investment? The Chinese experience. Journal of International Economics, 51(2): 379400.

Cleeve, A. E., Debrah, Y. and Yiheyis, Z. (2015). Human Capital and FDI Inflow: An 
Assessment of the African Case. World Development, 74: 1-14, 2015

Cleeve, E. (2008). How effective are fiscal incentives to attract FDI to Sub-Saharan Africa? The Journal of Developing Areas, 42(1): 135-153.

Denison, E. F. (1962). Sources of Economic Growth in the United States and alternative Before Us, New York: Committee for Economic development.

Dumartin, S. (1997). Formation Emploi : Quelle Adéquation ? Économie et Statistique, 303 : $59-80$.

Egger, P. (2001). European exports and outward foreign direct investment: A dynamic panel data approach. Review of World Economics, 137(3): 427-449.

Helpman, E. (1997). R\&D and productivity: The International connection. Discussion Paper No. 6101, NBER, Cambridge, MA.

Hong, J. (2008). WTO accession and foreign direct investment in China. Journal of Chinese Economic and Foreign Trade Studies, 1(2):136-147.

Keller, W. (2010). International trade, foreign direct investment, and technology spillovers. Handbook of the Economics of Innovation, 2: 793-829.

Liu, Z. (2008). Foreign direct investment and technology spillovers: Theory and evidence. Journal of Development Economics, 85(1-2): 176-193.

Lucas, R. (1998). On the Mechanics of Economic Development. Journal of Monetary Economics, 22(1): 3-42.

McMahon, W. W. and Boediono Eds (1992). Education and the Economy: The External Efficiency of Education. USAID, Educational Policy and Planning Project.

Melitz, M. J. (2003). The Impact of Trade on Intra-Industry Reallocations and Aggregate Industry Productivity. Econometrica, 71(6): 1695-1725.

Mincer, J. (1974), Schooling, Earnings, and Experience. New York: Colombia University Press.

Miyamoto, K. and Yasuyuki, T. (2006). Knowledge Spillovers from Foreign Direct Investment and the Role of Local R\&D Activities: Evidence from Indonesia. Economic Development and Cultural Change, (55) : 173-200.

Mouhoud, E. M. (2013). Mondialisation et délocalisation des entreprises. Paris: La Découverte.

Mughal, M.Y. and Vechiu, N. (2010). The Role of Foreign Direct Investment in Higher 
Education in the countries (Does FDI Promote Education?). Working Papers, 10/11/1, Université de Pau et des Pays de l'Adour.

Narula, R. (1996). Multinational investment and economic structure: Globalisation and Competitiveness. London: Routledge.

Naude, A.W. and Krugell, F. W. (2007). Investigating geography and institutions as determinants of foreign direct investment in Africa using panel data. Applied Economics, 39(10): 1223-1233.

Noorbakhsh, F., Paloni, A. and Youssef, A. (2001). Human Capital and FDI Inflows to countries: New Empirical Evidence. World Development, 29(9): 1593-1610.

Perotti, R. (1993). Political Equilibrium Income Distribution, and Growth. Review of Economic Studies, 60(4): 755-776.

Plassard, J.-M. and Tran, T. T. N. (2009). L'analyse de là sur éducation ou du déclassement : l'escroquerie scolaire enfin démasquée ou beaucoup de bruits pour rien ? Celui qui augmente sa connaissance augmente sa douleur (Ecclésiaste 18). Revue d'économie politique, 119(5): 751-793.

Poelhekke, S. and Van der Ploeg, F. (2016). Do Natural Resources Attract Non-resource FDI? Review of Economics and Statistics, July 2013, 95(3): 1047-1065.

Poelhekke, S. and Van der Ploeg, F. (2016). The Impact of Natural Resources: Survey of Recent Quantitative Evidence. The Journal of Development Studies, 1-12.

Psacharopoulos, G. (1986). Welfare effects of government intervention in education.

Contemporary Economic Policy, 4(3): 51-62.

Root, F. R. and Ahmed, A. A. (1978). The influence of policy instruments on manufacturing Direct Foreign investment in developing countries. Journal of International Business Studies, 9(3): 81-94.

Schultz, T.W. (1961). Investment in human Capital. American Economic Review, 51(1): 117.

Sheng, Y. and Xu, X. (2012). Productivity Spillovers from Foreign Direct Investment: FirmLevel Evidence from China. World Development, 40(1): 62-74.

Smith, M. R. (2001). Technological change, the demand for skills, and the adequacy of their supply. Canadian public policy, 27(1): 1-22.

Suyanto, S., Salim, A. R. and Bloch, H. (2009). Does Foreign Direct Investment Lead to Productivity Spillovers? Firm Level Evidence from Indonesia. World Development, 37(12):1861-1876 
Topel, H. R. (1997). Factor proportions and relative wages: The supply-side determinants of wage inequality. Journal of Economic Perspectives, 11(2): 55-74.

Trapp, K. (2015). Measuring the labor income share of countries: Learning from social accounting matrices. WIDER Working Paper 2015/041.

Vincens, J. (2005). L’adéquation formation-emploi. Paris : La Découverte.

World Bank (2015). Governance and finance analysis of the basic education sector in Nigeria. World Bank document, ACS14245.

$\mathrm{Xu}, \mathrm{B}$. (2000). Multinational enterprises, technology diffusion, and host country productivity growth. Journal of Development Economics, 62(2): 477-493.

Zhuang, H. (2008). Foreign direct investment and human capital accumulation in china. International Research Journal of Finance and Economics, 19: 205-15. 
APPENDIX

Annex: External efficiency by country (in percent)

\begin{tabular}{|c|c|c|c|c|c|}
\hline Country & Average efficiency & Country & Average efficiency & Country & Average efficiency \\
\hline Tajikistan & 1.4 & Papua New Guinea & 25.0 & South Africa & 60.9 \\
\hline Congo (Democratic Republic of the) & 2.6 & Côte d'Ivoire & 27.7 & Estonia & 61.0 \\
\hline Kyrgyzstan & 4.9 & Iran (Islamic Republic of) & 27.8 & Latvia & 62.9 \\
\hline Tanzania (United Republic of) & 5.6 & Romania & 28.1 & Panama & 63.0 \\
\hline Moldova (Republic of) & 7.8 & Peru & 29.7 & Hungary & 63.1 \\
\hline Mongolia & 7.9 & Russian Federation & 29.8 & Namibia & 67.6 \\
\hline Central African Republic & 8.2 & Algeria & 29.9 & Tunisia & 68.1 \\
\hline Cameroon & 11.2 & Paraguay & 29.9 & Czech Republic & 68.1 \\
\hline Lao People's Democratic Republic & 11.4 & Guinea & 30.7 & Jamaica & 69.9 \\
\hline Benin & 12.0 & Niger & 30.7 & Slovakia & 74.1 \\
\hline Azerbaijan & 12.3 & Botswana & 31.5 & Thailand & 76.3 \\
\hline Ukraine & 12.6 & China & 31.9 & Poland & 76.9 \\
\hline Armenia & 13.2 & Belarus & 34.1 & Mauritius & 77.1 \\
\hline Kenya & 14.9 & Jordan & 35.3 & Chile & 80.2 \\
\hline Chad & 16.1 & Egypt & 38.0 & Guatemala & 80.8 \\
\hline Senegal & 16.8 & Fiji & 38.6 & Mexico & 80.9 \\
\hline Philippines & 18.0 & Cuba & 41.4 & Venezuela (Bolivarian Republic of) & 82.0 \\
\hline Serbia & 18.9 & Bosnia and Herzegovina & 41.6 & Brazil & 82.4 \\
\hline Mauritania & 20.7 & Burkina Faso & 43.7 & Costa Rica & 83.1 \\
\hline Lesotho & 21.3 & Honduras & 44.0 & Trinidad and Tobago & 85.4 \\
\hline Kazakhstan & 21.4 & Grand Total & 44.3 & Argentina & 86.7 \\
\hline Sudan & 21.4 & Dominican Republic & 52.1 & Croatia & 86.8 \\
\hline Bolivia & 21.8 & Gabon & 56.4 & Turkey & 88.5 \\
\hline India & 22.4 & Mozambique & 57.5 & Uruguay & 90.2 \\
\hline Nicaragua & 23.8 & Colombia & 58.1 & Bahrain & 92.6 \\
\hline Sri Lanka & 23.8 & Lithuania & 58.1 & Saudi Arabia & 93.5 \\
\hline Bulgaria & 24.0 & Morocco & 60.1 & & \\
\hline
\end{tabular}

